Araştırma Makalesi / Research Article

\title{
Pasa Yığınları için Statik Koşullarda Şev Duraylılığının Araştırılmasının Önemi: Yeniköy Linyitleri İşletmesi Yaylıktepe Sahası Örneği
}

\author{
Importance of the Investigation of Slope Stability for Spoil Piles under Static Conditions: A \\ Case from Yayllktepe Site, Yeniköy Lignite Enterprises
}

\section{Hasan KARAKUL}

Maden Tetkik ve Arama Genel Müdürlüğ̈̈, Fizibilite Etütleri Dairesi, ANKARA

$\begin{array}{lll}\text { Geliş (received) } & : & \text { 05 Şubat (February) } 2014 \\ \text { Düzeltme (revised) } & : & \text { 17 Mart (March) } 2014 \\ \text { Kabul (accepted) } & : & \text { 21 Mart (March) } 2014\end{array}$

ÖZ

Açık işletmelerde cevhere ulaşmak için yapılan kazı sonucu elde edilen örtü (pasa) malzemesinin belirli alanlarda biriktirilmesi ve bu alanların doğaya yeniden kazandırılması çalışmaları madencilik sonucu doğada yaratılan tahribatların ortadan kaldırılabilmesi açısından oldukça önem taşımaktadır. Bu çalışmaların önemli bir aşaması da oluşturulacak pasa yığın şevlerinin duraylılı̆̆ının araştırılmasıdır. Bu çalışmada, Muğla-Milas Sekköy Linyit Açık İşletmesi Yaylık tepe sahasındaki pasa yığınları şev duraylılığ 1 açısından incelenmiştir. Fiziksel ve mekanik özelliklerinin tayin edilmesi amacıyla yapılan laboratuvar deneyleri sonucunda pasa malzemesinin yaklaşık olarak eşit oranlarda iri ve ince taneli malzeme içerdiği ve düşük plastisite indeksine sahip olduğu belirlenmiştir. Duraysızlık anında etkin olan makaslama dayanımı özelliklerinin belirlenmesi için sahada gözlenmiş pasa yığını duraysızlıkları geriye dönük analiz edilmişlerdir. Bu analizlerin sonuçlarıyla laboratuvar deneylerin sonuçları karşılaştırılmış ve duraysızlık anında pasa malzemesi için artık dayanımı özelliklerinin etkin olduğu anlaşılmıştır. Elde edilen veriler ve saha gözlemleri ışı̆̆ında çalışma alanındaki pasa yığını şevleri için Madencilik Faaliyetleri ile Bozulan Arazilerin Doğaya Yeniden Kazandırılması Yönetmeliği'nde belirtilen ilkeler gözetilerek, güvenli ve ekonomik olabilecek tek ve çok basamaklı pasa yığını şev geometrileri için tasarım analizleri gerçekleştirilmiştir. 10, 20 ve $30 \mathrm{~m}$ şev yükseklikleri dikkate alınarak yapılan analizlerde tek basamaklı şev profilleri için $20^{\circ}$ ile $40^{\circ}$ arasında, çok basamaklı şev profilleri için ise yaklaşık $19^{\circ}$ 'lik genel şev açısı değerleri belirlenmiştir.

Anahtar Kelimeler: Artık dayanım, Geriye dönük analiz, Pasa, Plastisite indeksi, Şev duraylılı̆̆1. 
Karakul

\section{ABSTRACT}

The studies related the deposition of the spoil piles, which is obtained by mining excavation in open pit mines, and the reclamation of the depositional areas are very important to overcome the induced destruction of the nature. A significant part of these studies is the investigation of the slope stability of spoil piles. In this study, slope stability analyses have been performed for the spoil piles of the Sekköy open pit mine in Muğla-Milas. Experimental results indicated that the spoil material includes nearly equal amount of coarse and fine grains, and has low plasticity index. With the purpose of determining the mobilized shear strength parameters at the time of failure, back analyses have been performed for the spoil pile failures observed in the study area. The comparison of data from the back analyses and the laboratory tests reveals that residual strength values were mobilized at the time of failure for the spoil material. By considering the data obtained and the field observations, one and multi-bench economical and safe slope design analyses have been performed for the spoil piles in the study area in accordance with the rules in the regulation on reclamation of the sites destructed by mining applications. According to the results of the analyses for 10, 20 and $30 \mathrm{~m}$ slope heights, 20-40 and $19^{\circ}$ overall slope angle values were determined for one and multi-bench slopes, respectively.

Key Words: Residual strength, Back analysis, Spoil, Plasticity index, Slope stability.

\section{GíRiș}

Açık işletme madenciliği yapılan alanlarda gerçekleştirilen madencilik faaliyetleri sonucu o alanlardaki doğal yapının bozulması söz konusu olmaktadır. Bu alanların doğaya yeniden kazandırılmasının önemli bir aşaması da madencilik faaliyetleri sonucunda elde edilen pasa yığınlarının duraylılığının incelenmesidir. Bugüne değin pasa yığınlarının duraylılığının incelenmesi ile ilgili olarak çok sayıda çalışma (Ulusay vd.,1994; Ulusay vd., 1995a; Ulusay vd.,1995b;. Stormont ve Farfan, 2005; Kaşmer ve Ulusay, 2006; Kaşmer vd., 2006; Jeldes vd., 2013; Bradfield vd., 2013) gerçekleştirilmiştir. Bu çalışmalardan bazıları (Ulusay vd.,1994; Ulusay vd.,1995a; Ulusay vd.,1995b) pasa yığınlarının fiziksel ve mekanik özelliklerinin belirlenmesi ve duraylılıklarının limit denge analiz yöntemleri ile araştırılması amacı ile gerçekleştirilmiştir. Pasa yığınlarının duraylılı̆̆ının limit denge analiz yöntemlerinin yanı sıra nümerik yöntemlerle de incelediği bazı çalışmalar da (Kaşmer ve Ulusay, 2006; Kaşmer vd. 2006) mevcuttur. Stormont ve Farfan (2005) diğer çalışmalardan farklı olarak pasa yığınlarının duraylılığının incelenmesinde sonsuz şev yönteminin kullanıldığı coğrafi bilgi sistemleri tabanlı bir model kullanmıştır. Jeldes vd., (2013) pasa yığınlarının duraylılıklarının değerlendirilmesi ile ilgili olarak doğaya yeniden kazandırılması kapsamında geliştirilmiş olan orman geri kazanım yaklaşımı ilkelerini esas almıştır. Bradfield vd. (2013) ise çok farklı tane boyutlarına sahip pasa malzemelerinin makaslama davranışının araştırılmasında daha büyük boyutlu örneklerin kullanılabildiği (0.72 $\mathrm{m} * 0.72 \mathrm{~m} * 0.6 \mathrm{~m})$ direk makaslama deney düzeneğinden yararlanmıştır. 
Yukarıda ifade edilen çalışmalardan farklı olarak bu çalışmada, Türkiye Kömür İşletmeleri (TKİ) tarafından işletilen Yeniköy Linyitleri İşletmesi'nde (YLİ) yer alan Yaylık tepe pasa döküm sahasındaki pasa yığınları için Çevre ve Orman Bakanlığı'nın 23 Ocak 2010 tarihli Madencilik Faaliyetleri ile Bozulan Arazilerin Doğaya Yeniden Kazandırılması Yönetmeliği'ndeki (2000) hususlar dikkate alınarak şev duraylılık çalışmaları gerçekleştirilmiştir. Söz konusu yönetmelikte, tek basamaklı şev tasarımları için $30^{\circ}$ üst sınırı mevcutken çok basamaklı şev tasarımları için basamak yüksekliğinin en fazla $3 \mathrm{~m}$ basamak genişliğinin ise en az $5 \mathrm{~m}$ olacak şekilde düzenlenmesi ile ilgili maddeler bulunmaktadır. Çalışma alanının yer bulduru haritası Şekil 1 'de, çalışma alanındaki pasa yığınlarının genel görünümü Şekil 2’de görülmektedir.

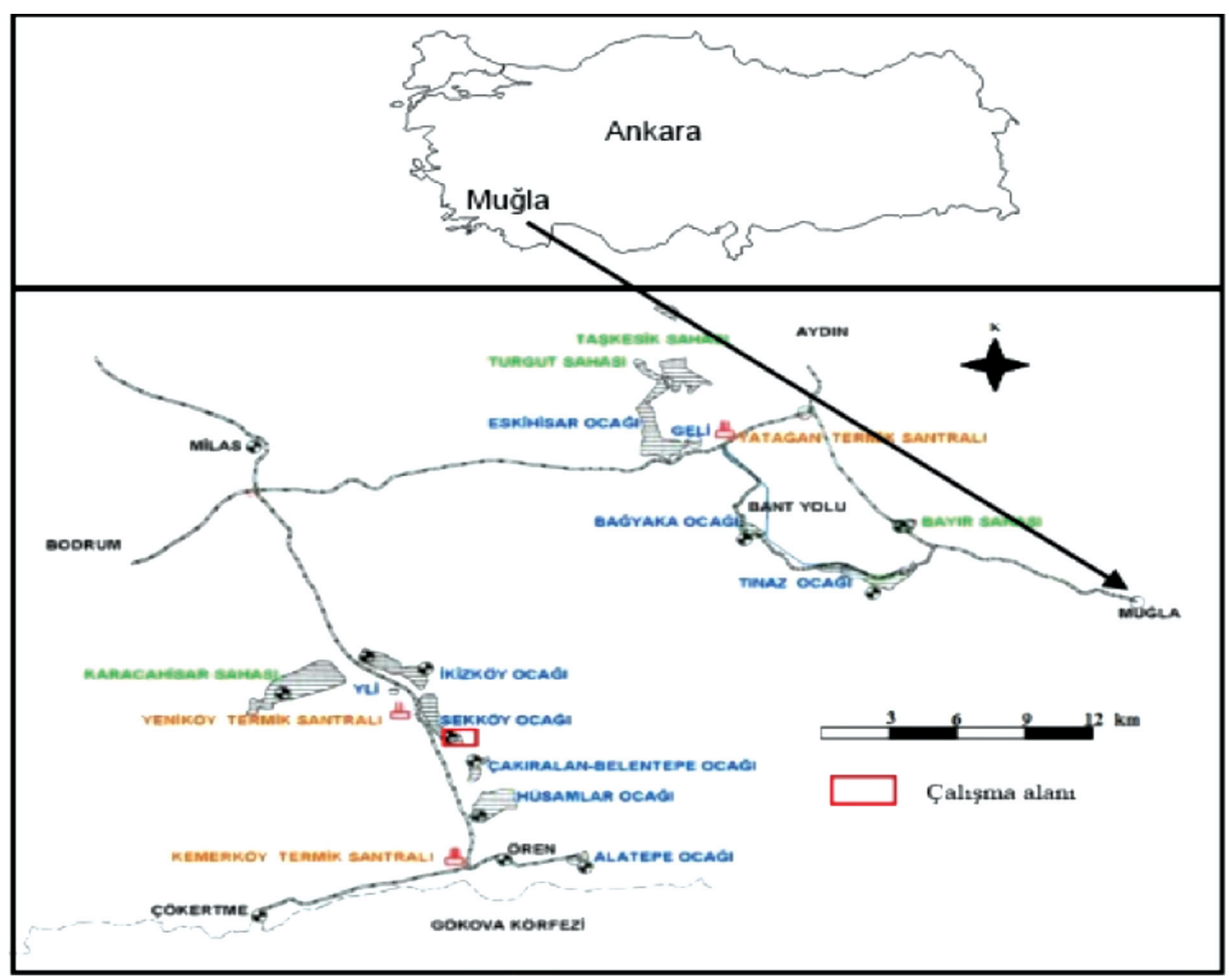

Şekil 1. Çalışma alanının yer bulduru haritası.

Figure 1. Location map of the study area. 
Karakul

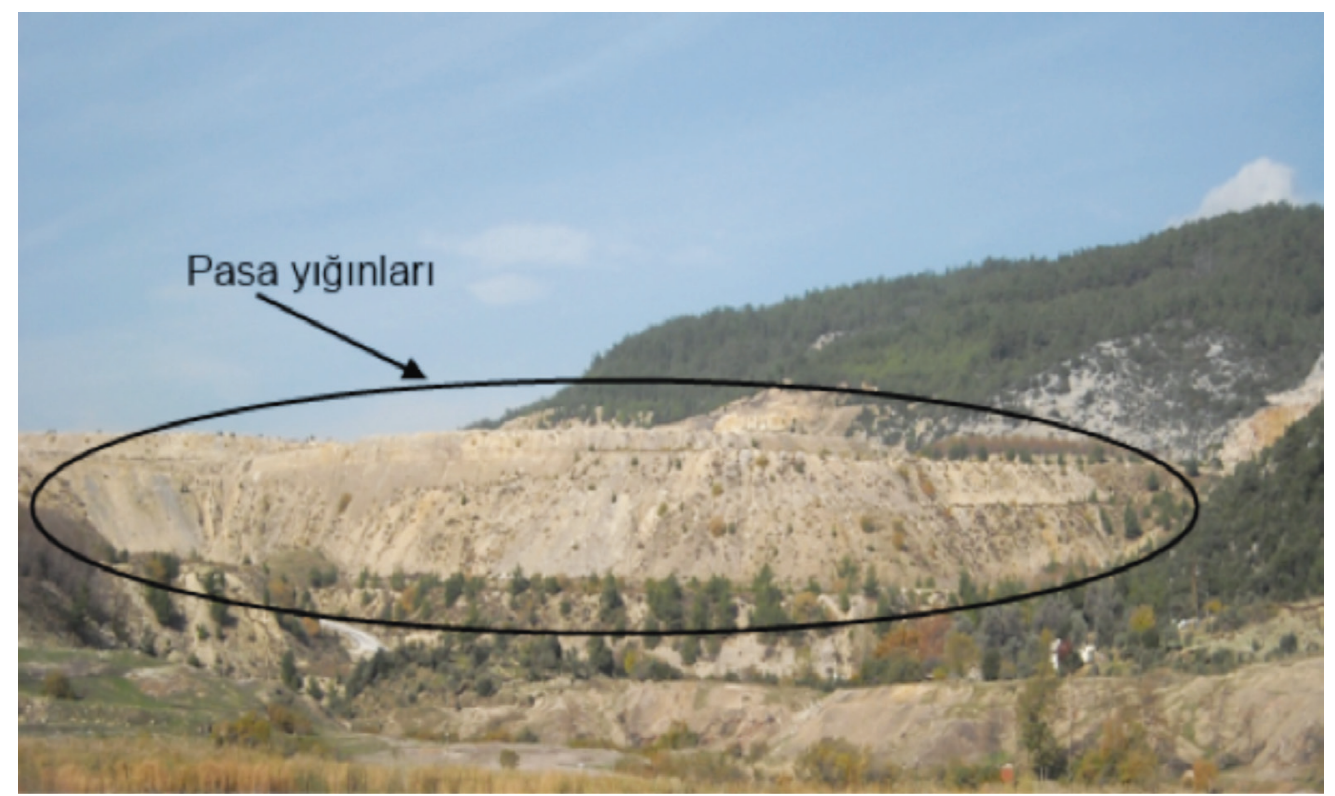

Şekil 2. Çalışma alanındaki pasa yığınlarının genel görünümü.

Figure 2. General view of the spoil piles in the study area.

Bu kapsamda öncelikle, çalışma alanında belirlenmiş olan duraysızlıklara yönelik gözlem ve araştırmalar yapılmıştır. Geçmişte meydana gelmiş duraysızlıkların incelenmesi sonucunda çalışma konusu olan pasa yığınlarının Sekköy formasyonuna ait marn-kireçtaşı birimlerinden oluşan sert taban üzerine yığılmış oldukları ve bu tip şevler için dairesel türde ve tabandaki kaya türü malzemeden bağımsız duraysızlıkların geliştiği gözlenmiştir. Gerçekleştirilen jeoteknik amaçlı saha çalışmaları kapsamında pasa malzemesine ait fiziksel ve mekanik özelliklerin tayininde kullanılmak amacıyla pasa yı̆̆ını içinden örselenmiş ve örselenmemiş örnekler alınmış ve bu örnekler üzerinde yapılan deneylerle pasa malzemesinin fiziksel ve mekanik özellikleri laboratuvarda belirlenmiştir. Ayrıca pasa malzemesi için duraysızlık anında (kayma yüzeyleri boyunca) etkin olan makaslama özelliklerinin (kohezyon ve içsel sürtünme açısı) belirlenmesi amacıyla söz konusu pasa döküm alanında gözlenen şev duraysızlıklarının geometrileri arazide alınan topoğrafik ölçümlerle belirlenmiş ve bunlarla ilgili geriye dönük analizler yapılmıştır. Bu aşamadan sonra ise, doğaya yeniden kazandırma yönetmeliğindeki ilkeler dikkate alınarak, incelenen döküm sahası için tek ve çok basamaklı pasa döküm şevlerinin güvenli ve ekonomik şekilde tasarımı için bir dizi şev duraylılık analizi gerçekleştirilmiştir. Son aşamada, günümüze değin şev tasarımı için kullanılmış olan güvenlik katsayısı değerleri ile Madencilik Faaliyetleri ile Bozulan Arazilerin Doğaya Yeniden Kazandırılması Yönetmeliği’nde ifade edilmiş düzenlemeler için elde edilen şev tasarımları karşılaştırılmış ve her iki koşulu da sağlayan tasarım önerileri geliştirilmiştir. 


\section{ÇALIŞMA ALANININ JEOLOJİSi}

Çalışma alanında Neojen öncesi kayaçlar ve Neojen çökelleri olmak üzere iki ana stratigrafik birim bulunmaktadır (Yiğitel, 1978; Yücel vd., 1990). Neojen öncesi kayaçlar sahanın güneyinde yayılım gösteren Paleozoyik şistler ve doğu kesimindeki kireçtaşlarıdır. Neojen çökelleri ise yaşlıdan gence doğru; taban serisi (Turgut formasyonu), kömür band1, marn-kireçtaşı serisi (Sekköy formasyonu), yamaç molozları ve alüvyondan oluşmaktadır. Turgut formasyonu olarak adlandirılan taban serisi esas olarak konglomera, kum, silt ve çakıl içeriğine sahip yüksek plastisiteli kil seviyelerinden ibarettir. $\mathrm{Bu}$ serinin üzerinde bej renkli kil ve kiltaşlarından oluşan ara kesmeler içeren kömür bantları görülmektedir (Yücel vd., 1990). Kömür band1 üzerinde marn-kireçtaşı serisi bulunmaktadır. Kömür bandınıda içeren bu seri Sekköy formasyonu olarak adlandırılmaktadır (Yiğitel,
1978). Kompakt marnlar, kömür bandının hemen üzerinde yaklaşık 4 metrelik kalın tabakalara sahip olup, daha üst seviyelerde laminalı marnlar bulunmaktadır. Laminalı marnlar gri ve bej renkli olup siltli, killi ve kalkerli ardalanmalar göstermektedir. Daha üst seviyelerde ise, tabaka kalınlığı yaklaşık $20 \mathrm{~cm}$ olan kireçtaşları bulunmaktadır. Apaydın ve Ulusay (1990), laminalı marn ve kireçtaşları arasında ise kılavuz bir kil seviyesinin bulunduğunu belirtmiştir. Boz renkli ve yaklaşık $1 \mathrm{~m}$ kalınlığa sahip bu siltli kil seviyesinin X-1şınları kırınım analizleri (XRD) sonuçlarına göre montmorillonit ve az miktarda illit içerdiği belirlenmiştir (Apaydın ve Ulusay, 1990). Marn-kireçtaşı serisinin üzerinde sırasıyla yamaç molozları ve alüvyon birimleri bulunmakta olup, bu birimler özellikle sahanın batısında geniş yer kaplamaktadır. Çalışma alanındaki pasa yığınları büyük ölçüde Sekköy formasyonuna ait kompakt ve laminalı marnlardan oluşmaktadır.

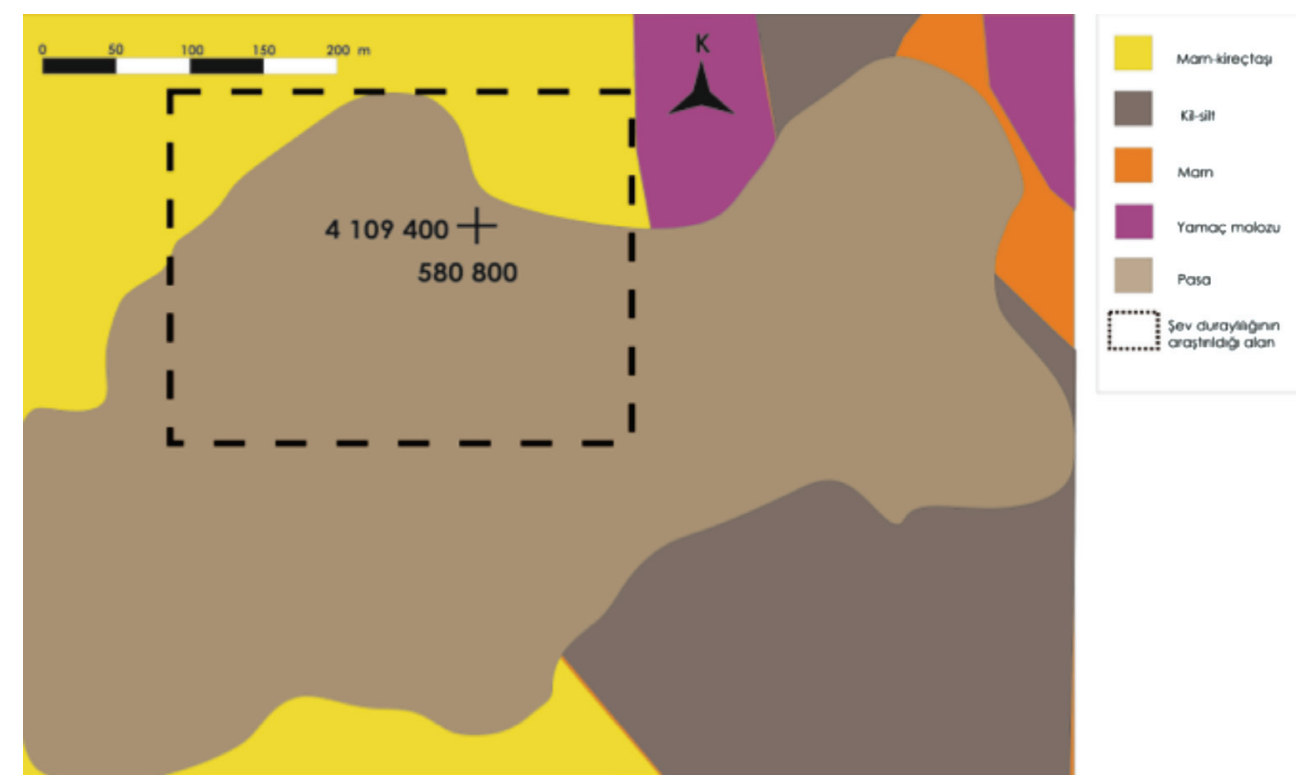

Şekil 3. Çalışma sahasının basitleştirilmiş jeoloji haritası.

Figure 3. Simplified geological map of the study area. 
Karakul

\section{ÖRNEKLEME}

Çalışma alanındaki pasa malzemesinin amaca uygun fiziksel ve mekanik özelliklerinin tayini için dökümlerin bazı kesimlerinden örselenmiş ve örselenmemiş örnekler alınmıştır. Örselenmemiş örnekler ince ağızlı metal kesici kalıplar ve $20 \mathrm{~cm}$ çap ve $45 \mathrm{~cm}$ yüksekliğe sahip ince çeperli tüpler kullanılarak alınmıştır.
Örnekleme sirasında örselenmenin en alt düzeyde tutulması amacıyla ince çeperli tüpler kepçe yardımıyla zemine itilmiştir. Örnekler duraysızlıkların kayma aynalarına komşu konumda bulunan pasa malzemesinden, pasa kütlesi içerisinden ve yerinde birim hacim ağırlık tayininde kullanılmak üzere belirli bir geometri sağlanacak şekilde kepçeyle açılmış olan üç çukurdan elde edilmiştir (Şekil 4).

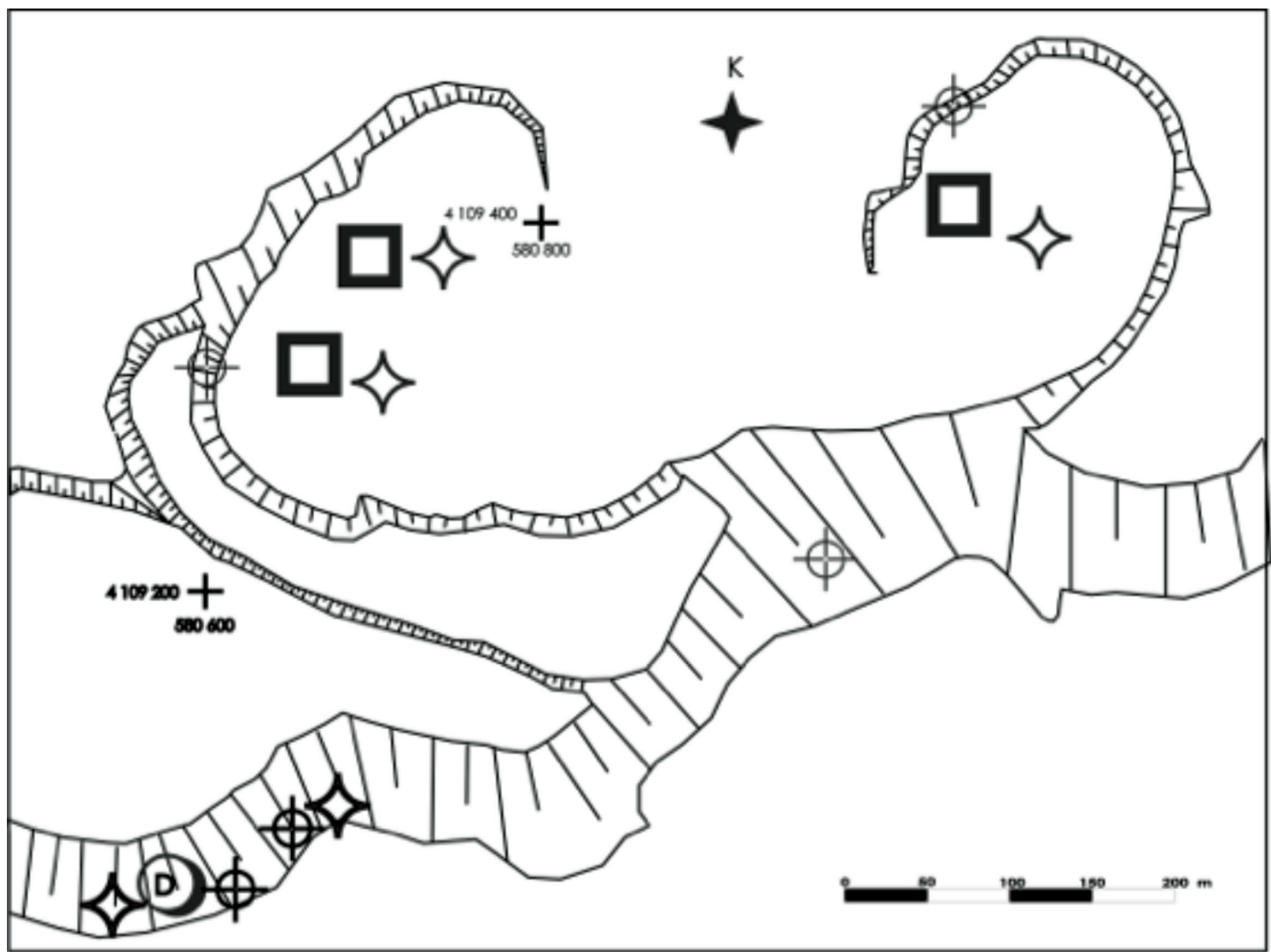

||||$\quad$ Pasa şevi

D

Şev duraysızlığı

Yoğunluk çukuru

Ð Örselenmemiş örnek

Orselenmiş örnek

Şekil 4. Çalışma alanındaki pasa yığınlarının planı ve örnekleme yapılan lokasyonlar.

Figure 4. The plan of the spoil piles and sampling locations in the study area. 
Malzemedeki dağılma nedeniyle kuru koşullarda örnek alımının oldukça güç olduğu pasa malzemesinden, kaliteli ve temsil edici nitelikte örnek almak için, taneler arası bağlantıyı yüzey gerilmesi yoluyla sağlayabileceği (malzemeye yalanc1 kohezyon kazandirma amacıyla) dikkate alınarak örnekleme bölgesi az miktarda suyla 1slatılmıştır (Şekil 5).

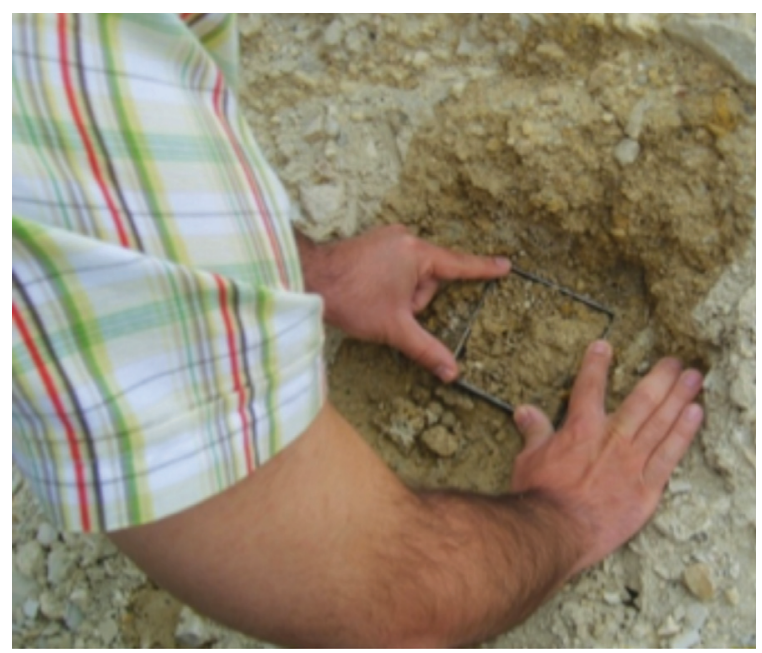

Şekil 5. Suyla ıslatılmış pasadan örselenmemiş örnek alımı.

Figure 5. Undisturbed sampling for the wetted spoil material.

Örselenmemiş örnekler örnekleyici üzerine sarılan tülbent ve gerçekleştirilen parafinleme işlemleri sonrasında laboratuvara nakledilmiştir. Açılan çukurlarda pasa malzemesinin yerindeki ortalama doğal birim hacim ağırlı̆̆ $13.8 \mathrm{kN} / \mathrm{m}^{3}$ olarak belirlenmiştir.

\section{JEOMEKANIK ÖZELLIKLERIN TAYINII}

Çalışma sahasından alınmış olan örselenmiş ve örselenmemiş örnekler kullanılarak pasa malzemesinin bazı fiziksel ve mekanik özellikleri laboratuvarda belirlenmiştir. Fiziksel özelliklerin tayini kapsamında tane boyu dağılımı, özgül ağırlık, birim hacim ağırlık, su içeriği ve Atterberg Limitleri belirlenmiştir. Mekanik özelliklerin tayini kapsamında ise, birim-deformasyon kontrollü konsolidasyonludrenajlı makaslama deneyleri yapılarak pasa malzemesinin makaslama dayanımı özellikleri (kohezyon ve içsel sürtünme açısı)belirlenmiştir. Laboratuvar deneylerinde ASTM (1994a) standartları esas alınmıştır.

\section{a) Fiziksel ve indeks özellikler}

Tane boyu dağılım analizleri, 1slak elek ve hidrometre analizi olmak üzere iki aşamada gerçekleştirilmiştir. Başlangıçta marn bloklarından oluşan pasa malzemesinin zamanla üstüne yı̆̆glan yeni malzemelerin ağırlığı, iş makinası trafiğine bağlı yükler ve atmosferik koşullarla dağılması sonucu ince tane miktarında artış olmaktadır. Elek analizlerinde standart eleklerde kullanılması mümkün olmayan büyük çaplı bloklar kullanılmamıştır. Beş farklı yerden elde edilmiş örselenmiş örnekler üzerinde gerçekleştirilen tane boyu dağılım analizlerinin sonuçlarına göre elde edilmiş eğriler ve tane boyu yüzdeleri Şekil 6'da ve Çizelge 1'de verilmiştir. 
Karakul

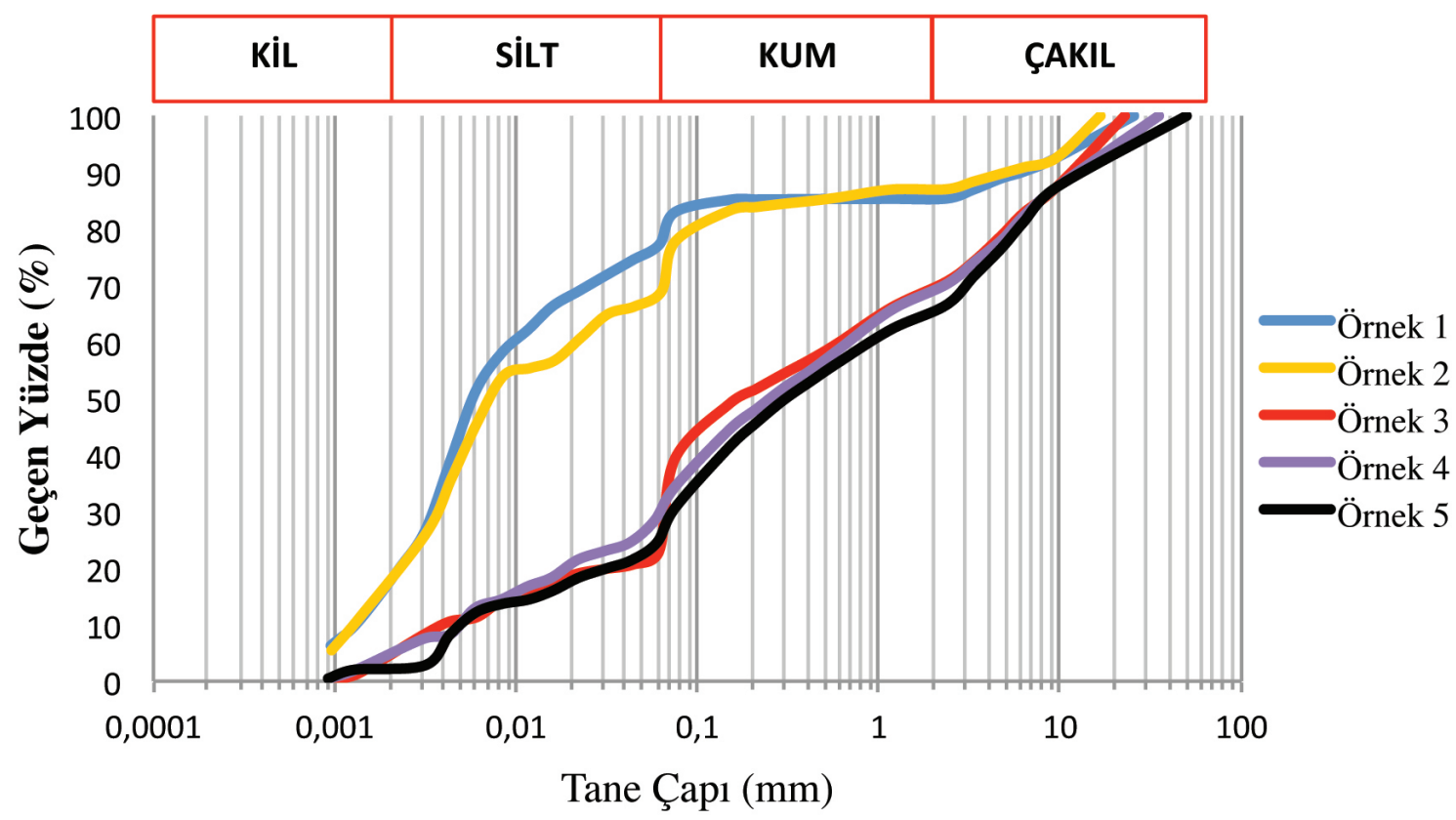

Şekil 6. Pasa malzemesi örneklerinin tane boyu dağılım eğrileri.

Figure 6. Grain size distribution curves of the samples from the spoil material

Çizelge 1. Pasa malzemesinin içerdiği tane boyu yüzdeleri.

Table 1. Grain size percentages of the spoil material.

\begin{tabular}{ccccc}
\hline \multicolumn{5}{c}{ Tane boyu } \\
\hline Örnek No. & KİL (\%) & SíLT (\%) & KUM (\%) & ÇAKIL (\%) \\
\hline S1 & 18 & 58 & 9 & 15 \\
S2 & 21 & 46 & 21 & 12 \\
S3 & 8 & 30 & 32 & 30 \\
S4 & 7 & 20 & 43 & 30 \\
S5 & 5 & 22 & 40 & 33 \\
\hline
\end{tabular}

Çizelge 1'den görülebileceği gibi, pasa malzemesi $\% 47$ ince ve $\% 53$ iri tane içermektedir. Pasa malzemesi örneklerinden belirlenmiş olan ortalama özgül ağırlık, birim hacim ağırlık ve su içeriği değerleri Çizelge 2'de verilmiştir. Bu sonuçlara göre, laboratuvarda belirlenen birim hacim ağırlık değerleri arazide örnek alımı sirasinda uygulanan nemlendirme nedeniyle yerinde tayin edilen değerlere göre biraz daha yüksek çıkmıştır. Pasa malzemesi örneklerinin 
Çizelge 2. Pasa malzemesi için belirlenen özgül ağırlık, birim hacim ağırlık ve su içeriği değerleri.

Table 2. Specific gravity, unit weight and water content values of the spoil material.

\begin{tabular}{ccc}
\hline Özgül ağırlık & Birim hacim ağırlık $\left(\mathrm{kN} / \mathrm{m}^{3}\right)$ & Su içeriği (\%) \\
\hline 2.65 & 15 & 21 \\
\hline
\end{tabular}

Atterberg Limitleri, sirasıyla likit limit (LL) $=$ $\%$ 41.1, plastik limit (PL) $=\% 25.6$ ve plastisite indeksi $(\mathrm{PI})=\% 15.6$ olarak belirlenmiştir.

Farklı çalışmalarda da (Ulusay vd., 1995a; Jeldes vd., 2013) marn, kireçtaşı ve kiltaşı gibi birimlerinden oluşan pasa yığınları için benzer PI değerleri (12-15 (Ulusay vd., 1995a) ve 18.6 (Jeldes vd., 2013)) belirlenmiştir. Pasa malzemesi için belirlenmiş olan tane boyu dağılımı ve Atterberg Limitleridikkate alınarak, Birleştirilmiş Zemin Sinıflaması'na (ASTM, 1994b) göre malzemenin mühendislik sınıflaması yapılmıştır. Söz konusu sınıflama, yaklaşık eşit oranlarda iri ve ince tane içeren pasa malzemesinin zemin sınıfının iri ve ince tanelerin sınıflarının birlikte değerlendirilmesiyle, ince tane yüzdesi iri taneye oranla daha fazla olan örnekler için ise plastisite abağından yararlanılarak elde edilmiştir. Beş adet örnekten ikisinin killi kum-düşük plastisiteli silt (SC-ML), diğerlerinin ise killi kum-düşük plastisiteli kil (SC-CL), düşük plastisiteli kil (CL) ve düşük plastisiteli silt-düşük plastisiteli organik zemin (ML-OL) zemin sinıflarında yer aldıkları belirlenmiştir. Pasa malzemesinin ince taneli kısmını temsil eden örneklerin plastisite abağı üzerindeki dağılımları Şekil 7'de görülmektedir.

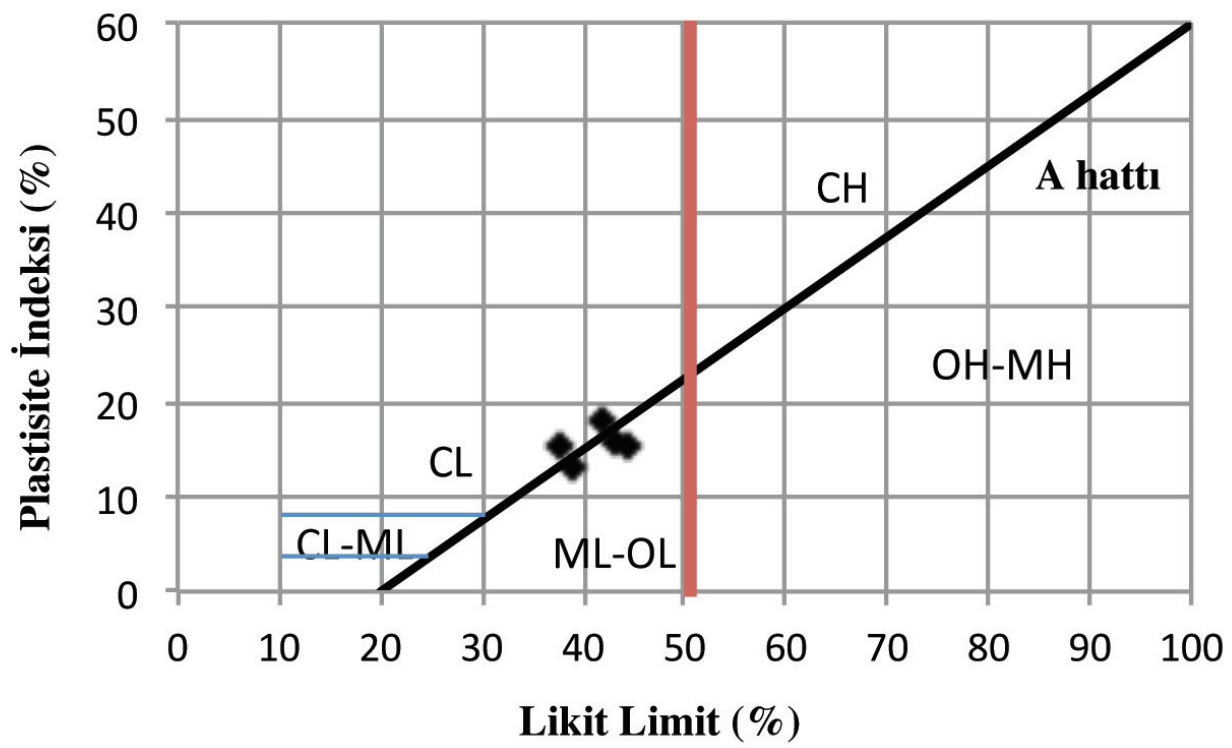

Şekil 7. Pasa malzemesinin ince taneli kısmını temsil eden örneklerin plastisite abağı üzerindeki dağılımları.

Figure 7. The distribution of the fine-grained samples of the spoil material on the plasticity chart. 
Karakul

\section{b) Pasa malzemesinin makaslama dayanımı}

Şev duraylılık analizleri için başlıca girdi parametresi olan makaslama dayanımı özellikleri, araziden alınan örneküzerindeyapılanmakaslama deneyleriyle tayin edilmiştir. Ulusay vd. (1994), pasanın değişik tane boyutlarına sahip zemin niteliğinde bir malzeme olduğunu ifade etmiştir. $\mathrm{Bu}$ çalışmada da pasa malzemesinin \% 47 ince ve \% 53 iri tane boyutundan oluşan bir tane boyu bileşimine sahip olduğu belirlenmiştir. $\mathrm{Bu}$ nedenle pasa malzemesinin makaslama dayanımı özelliklerinin belirlenmesi amacı ile zemin makaslama deneyleri yapılmıştır. Bu deneylerde ince çeperli tüpler ve $10 * 10 * 3 \mathrm{~cm}$ boyutlarındaki metal kesici kalıplar kullanılarak hazırlanmış olan örselenmemiş örnekler kullanılmıştır. Konsolidasyonlu-drenajlı deney yöntemiyle gerçekleştirilen makaslama deneylerinde, her biri en az 3 örnekten oluşan toplam 7 deney seti kullanılmıştır. İri tanelerin yoğun olarak bulunduğu pasa malzemesi için makaslama deneyleri $0.21 \mathrm{~mm} / \mathrm{dk}$ 'lık makaslama hızıyla yapılmıştır. Bu deneylerin sonuçları Çizelge 3 'te, yenilme zarfları ise Şekil 8'de verilmiştir.

Çizelge 3 ve Şekil 8'den görülebileceği gibi pasa malzemesine ait makaslama deney sonuçları doğrusal yenilme zarfına uyum göstermiş ve bu nedenle analizlerde Mohr-Coulomb yenilme kriteri kullanılmıştır.

Ulusay vd. (1994) Muğla-Yatağan'da bulunan ve büyük ölçüde aynı malzemeden oluşan pasa yığınları için bu çalışmadaki sonuçlara çok yakın değerler $\left(c_{r}=8.9 \mathrm{kPa}\right.$ ve $\varphi_{\mathrm{r}}=33^{\circ}$ ve $\mathrm{c}_{\mathrm{p}}=12 \mathrm{kPa}$ ve $\varphi_{\mathrm{p}}=34.3^{\circ}$ ) belirlemişlerdir. Marn ve kireçtaşı birimlerinden oluşan pasa yığınları için Kaşmer ve Ulusay (2006) ile pasayı oluşturan kaya türünün belirtilmediği Colorado'daki pasa yığınları için ise Stormont ve Farfan (2005) tarafindan yakın sonuçlar (sırasıyla $\mathrm{c}_{\mathrm{r}}=5 \mathrm{kPa}$ ve $\varphi_{\mathrm{r}}=37^{\circ}$ ile $\mathrm{c}_{\mathrm{r}}=6-10 \mathrm{kPa}$ ve $\varphi_{\mathrm{r}}=24-33^{\circ}$ ) elde etmişlerdir.

Çizelge 3. Konsolidasyonlu-drenajlı zemin makaslama deneylerinden belirlenmiş yenilme zarflarına göre örneklerin kohezyon (c) ve içsel sürtünme açıları (f) ile yenilme zarflarının korelasyon katsayıları (r).

Table 3. Cohesion (c), internal friction angle (f) and correlation coefficient $(r)$ of the failure envelope for the test specimens determined by consolidated-drained shear box tests.

\begin{tabular}{|c|c|c|c|c|c|c|}
\hline \multirow[b]{2}{*}{ Örnek seti } & \multicolumn{3}{|c|}{ Doruk Makaslama } & \multicolumn{3}{|c|}{ Artık makaslama } \\
\hline & $\mathrm{c}_{\mathrm{p}}(\mathrm{kPa})$ & $\mathrm{f}_{\mathrm{p}}($ derece $)$ & $\mathrm{r}$ & $\mathrm{c}_{\mathrm{r}}(\mathrm{kPa})$ & $\mathrm{f}_{\mathrm{r}}($ derece $)$ & $\mathrm{r}$ \\
\hline 1 & 5.7 & 37.4 & 0.997 & 5.6 & 36.2 & 0.997 \\
\hline 2 & 32.7 & 27.6 & 0.937 & 21.9 & 27.8 & 0.934 \\
\hline 3 & 10 & 33.5 & 0.988 & 3.5 & 34 & 0.987 \\
\hline 4 & 12.2 & 24.4 & 0.966 & 10.5 & 23.9 & 0.969 \\
\hline 5 & 24.5 & 23.5 & 0.949 & 19.1 & 23.9 & 0.963 \\
\hline 6 & 14.8 & 34.1 & 0.998 & 12.9 & 32.6 & 0.999 \\
\hline $\begin{array}{l}7 \\
\text { Genellestirilmis }\end{array}$ & 8.4 & 35 & 0.996 & 1.3 & 34.1 & 0.997 \\
\hline yenilme zarfı & 12.1 & 31.2 & 0.94 & 8.6 & 30.6 & 0.94 \\
\hline
\end{tabular}




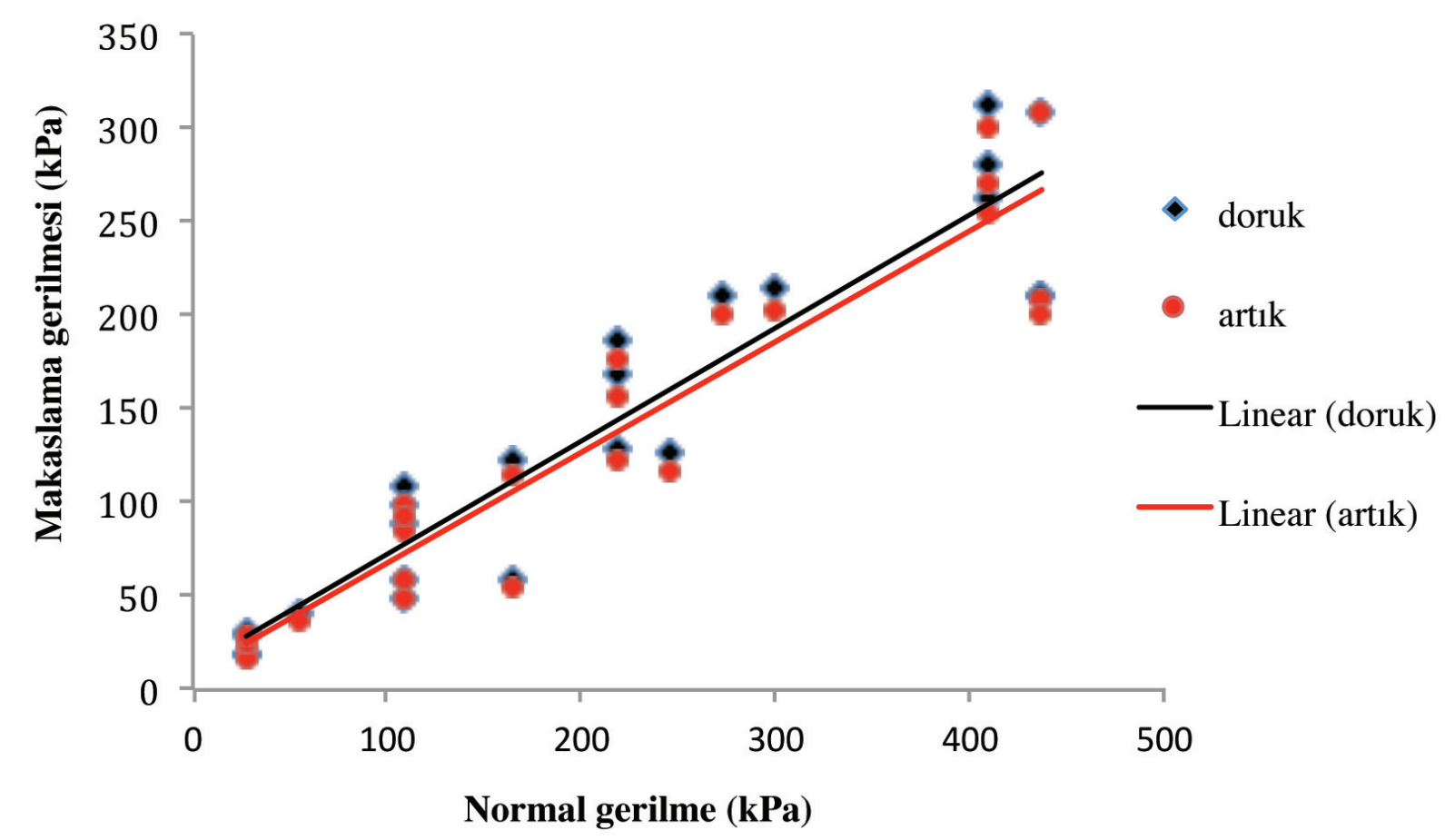

Şekil 8. Pasa malzemesi için tüm makaslama deneylerinin sonuçları esas alınarak belirlenmiş doruk ve artık makaslama koşullarını temsil eden genelleştirilmiş doğrusal yenilme zarfları.

Figure 8. Generalised linear peak and residual failure envelopes determined by the direct shear tests for the spoil material.

\section{DURAYSIZLIĞA UĞRAMIŞ PASA YIĞINLARININ GERIYYE DÖNÜK ANALIZi}

Pasa malzemesinin kazı, döküm sahasına nakliye ve yığılma süreçlerinde oldukça yüksek düzeyde örselenmeye maruz kalması, atmosferik etkiler ve yağış gibi faktörlerle dağılıp ufalanması ve kısmen de ayrışması söz konusu olup, bu süreçlere bağlı olarak gelişen deformasyonlar sonucunda, malzemede örnekleme öncesi örselenme söz konusu olmaktadır. Büyük ölçüde aynı malzemeden oluşan pasa yı̆̆ını duraysızlıkları için yapılmış geriye dönük analizlerin sonucunda da duraysızlık anında artık makaslama dayanımının etkin olduğu Ulusay vd. (1994) tarafından vurgulanmıştır. Ulusay vd. (1995a), Ulusay vd. (1995b), Kaşmer vd. (2006) gibi bazı çalışmalarda da farklı birimlerden oluşmuş pasa yığınları için duraysızlık esnasında artık makaslama dayanımı özelliklerinin geçerli olduğu belirlenmiştir. $\mathrm{Bu}$ çalışmada da pasa malzemesinin duraysızlık anında etkin olan makaslama özelliklerinin tayini amaciyla geriye dönük analizler gerçekleştirilmiştir. Bu amaçla Yaylık tepe güneyindeki pasa yığınında daha önceki yıllarda gelişmiş bir duraysızlık (Şekil 9) için iki farklı doğrultuda arazi ölçümleriyle hazırlanmış kayma kesitleri boyunca geriye dönük analizler yapılmıştır. 
Karakul

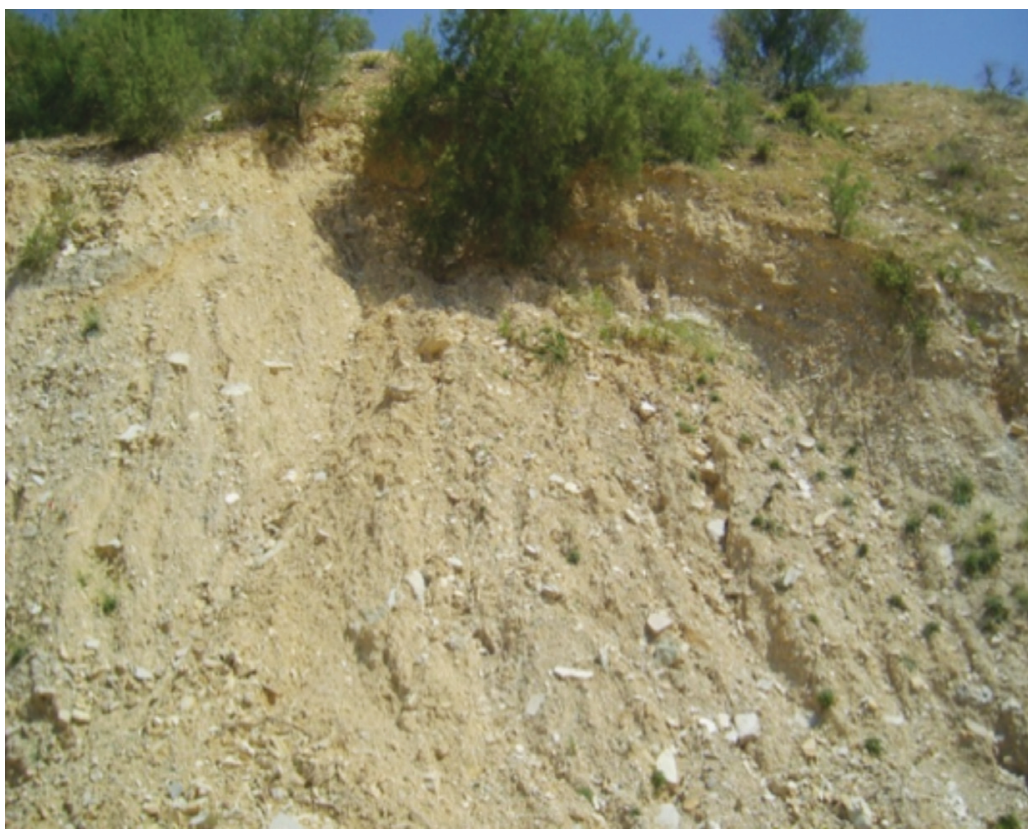

Şekil 9. Geriye dönük analizi yapılan pasa şevi duraysızlı̆̆1.

Figure 9. The spoil slope instability for which back analysis was performed.

Geriye dönük analizlerde kullanılan ve göre çizilmiş 1/500 ölçekli duraysızlık planı ve döküm sahasında yapılmış topoğrafik ölçümlere analiz kesit doğrultuları Şekil 10'da verilmiştir.

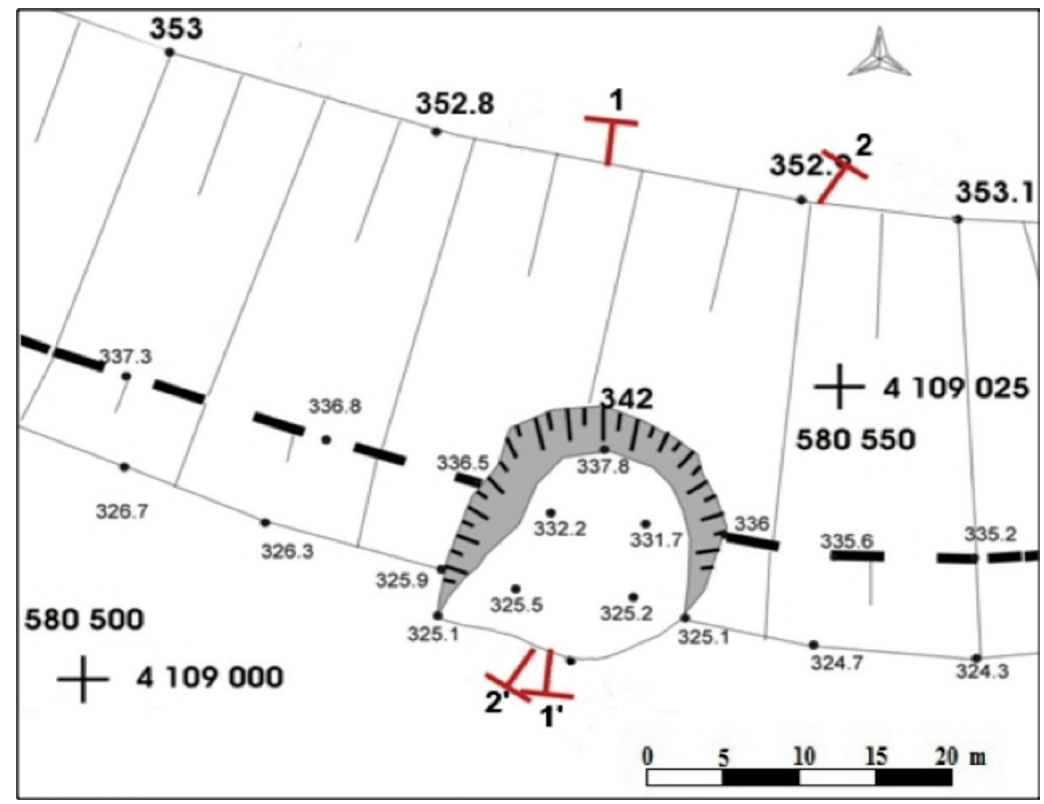

Şekil 10. Yaylık Tepe güneyindeki pasa şevinde meydana gelmiş eski duraysızlığın planı.

Figure 10. The plan view of the old slope instability in the south of the Yaylik Tepe site. 
Dairesel kayma türünde gelişmiş olan duraysızlık için arazide gözlenen kayma yüzeyi geometrisi esas alınarak Şekil 11'de kayma yüzeylerinin de gösterildiği 2 farklı duraysızlık kesiti için limit denge $(F=1)$ koşulunu sağlayan c ve $\Phi$ çiftleri belirlenmiş ve bunlara ait zarflar ise Şekil 12'de verilmiştir. Şekil 12'den görülebileceği gibi, zarfların kesişme bölgeleri laboratuvarda tayin edilmiş

\section{Kesit 1}

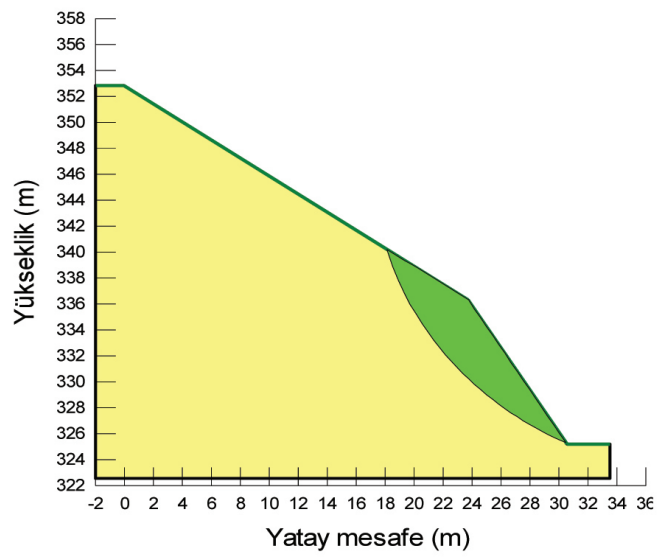

olan artık makaslama dayanımı özelliklerinin değişim aralığ 1 içinde yer almaktadır. Geriye dönük analizler sonucunda belirlenen zarfların kesişme konumlarının artık makaslama dayanımı parametreleriyle uyum içerisinde olması göz önünde bulundurularak, bundan sonraki bölümlerde verilen tasarıma yönelik durayl111k analizlerinde pasa malzemesinin artık makaslama dayanım özellikleri kullanılmıştır.

\section{Kesit 2}

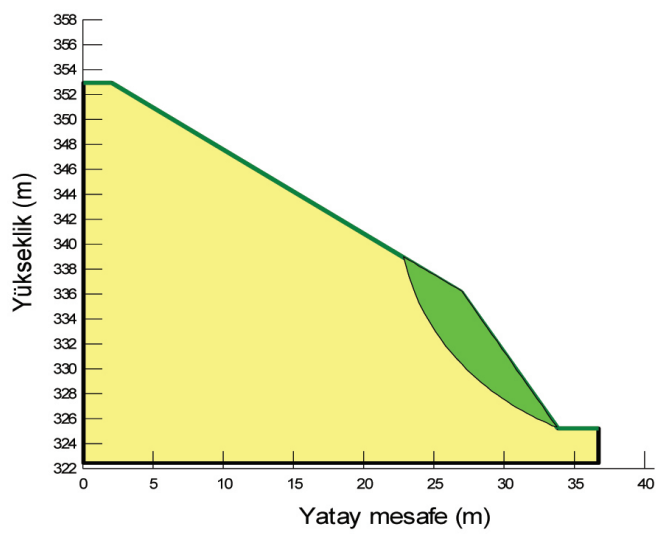

Şekil 11. Geriye dönük analizlerde kullanılan duraysız şev kesitlerinde tanımlanan kayma kütleleri.

Figure 11. The sliding mass of the slope sections used in the back analyses.

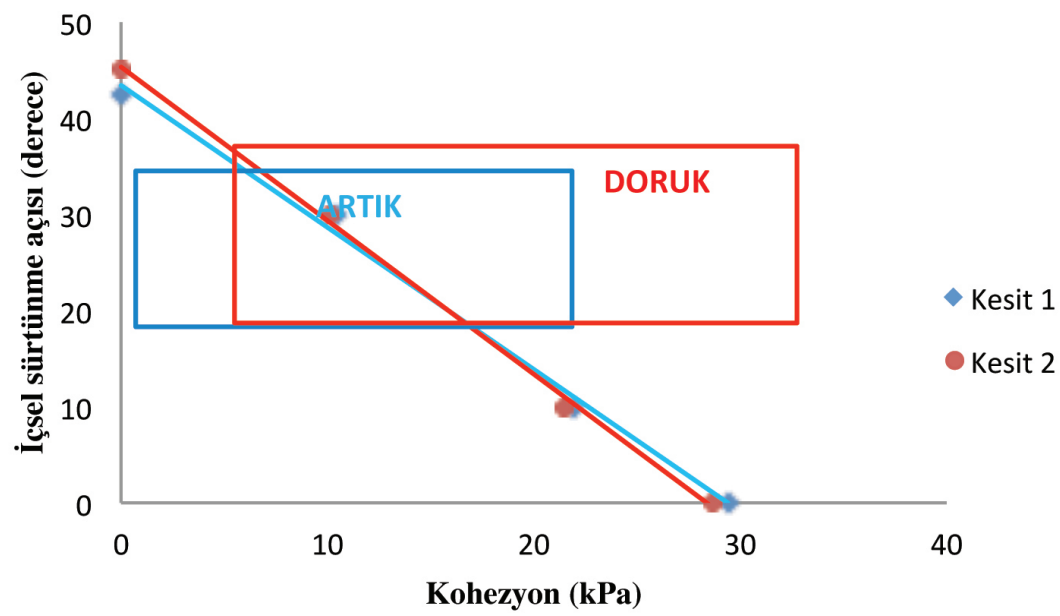

Şekil 12. Geriye dönük analiz sonuçları ile laboratuvarda belirlenen makaslama dayanım parametreleri aralığının karşılaştırılması. Figure 12. The comparision of the back analysis results and the range of shear strength parameters determined in the laboratory. 
Karakul

\section{PASA YIĞINLARININ TASARIMIYLA ILGILİ ŞEV DURAYLILIĞI ANALIZLERİ}

Çalışma sahasındaki pasa yığınlarının güvenli ve ekonomik şekilde tasarımı amacıyla limit denge analiz yöntemi kullanılarak şev duraylılık analizleri gerçekleştirilmiştir. Çalışma alanındaki pasa yı̆̆ınlarının Sekköy formasyonuna ait marn-kireçtaşı birimlerinden oluşan sert bir taban üzerine yığılmış olması nedeniyle, daha önce gelişmiş olan duraysızlıkların dairesel türde ve tabandan bağımsız olarak geliştiği gözlenmiştir. $\mathrm{Bu}$ nedenle sert kaya taban üzerine dökülmüş olan pasa yığınlarının duraylılık analizlerinde duraysızlık modeli tabandan bağımsız olarak düşünülmüştür. Sert taban üzerine yığılmış pasalardaki duraysızlık modeli farklı çalışmalarda da (Ulusay vd., 1994; Ulusay vd., 1995a; Ulusay vd., 1995b) dairesel türde ve tabandan bağımsız olarak belirlenmiştir. Daha önce Sekköy formasyonuna ait pasa malzemeleri için Yatağan-Eskihisar linyit açık işletmesinde Ulusay vd. (1994) tarafindan yapılan çalışmalarda gerçekleştirilen sondajlar ve açılan gözlem çukurlarında herhangi bir serbest su yüzeyine rastlanılmamış olup, bu çalışmada da şevlerin topuk bölgelerinde açılan sı̆̆ derinlikli gözlem çukurlarında suya rastlanılmamıştır. Bununla birlikte Ulusay vd., (1995a) şiddetli yağış dönemlerinde yağış sularının sızması sonucu pasalar içinde sı̆̆ da olsa bir su varlığının gelişebileceğini ifade etmiştir. Bradfield vd., (2013) bu güne değin pasa yı̆̆ınları için gerçekleştirilmiş olan çalışmalar değerlendirildiğinde pasa yığınları içinde en yüksek 3-5 m düzeyinde ve topuğa doğru alçalan bir su tablasının mümkün olabileceğini ifade etmiştir. Dolayısıyla pasa malzemesi içerisinde oldukça sı̆̆ bir serbest su yüzeyinin gelişmesi ihtimali de şev duraylılık analizlerinde dikkate alınmıştır. Su tablalı analizlerde Bradfield vd., (2013) tarafindan vurgulanan topuğa doğru alçalan 5 metrelik olası en yüksek su tablası profili dikkate alınmıştır (Şekil 13).

Analizlerde örnekleme çukurları kullanılarak yerinde tayin edilmiş olan birim hacim ağırlık değeri $\left(13.8 \mathrm{kN} / \mathrm{m}^{3}\right)$ kullanılmıştır. İlk aşamada tek basamaklı şev geometrisi için

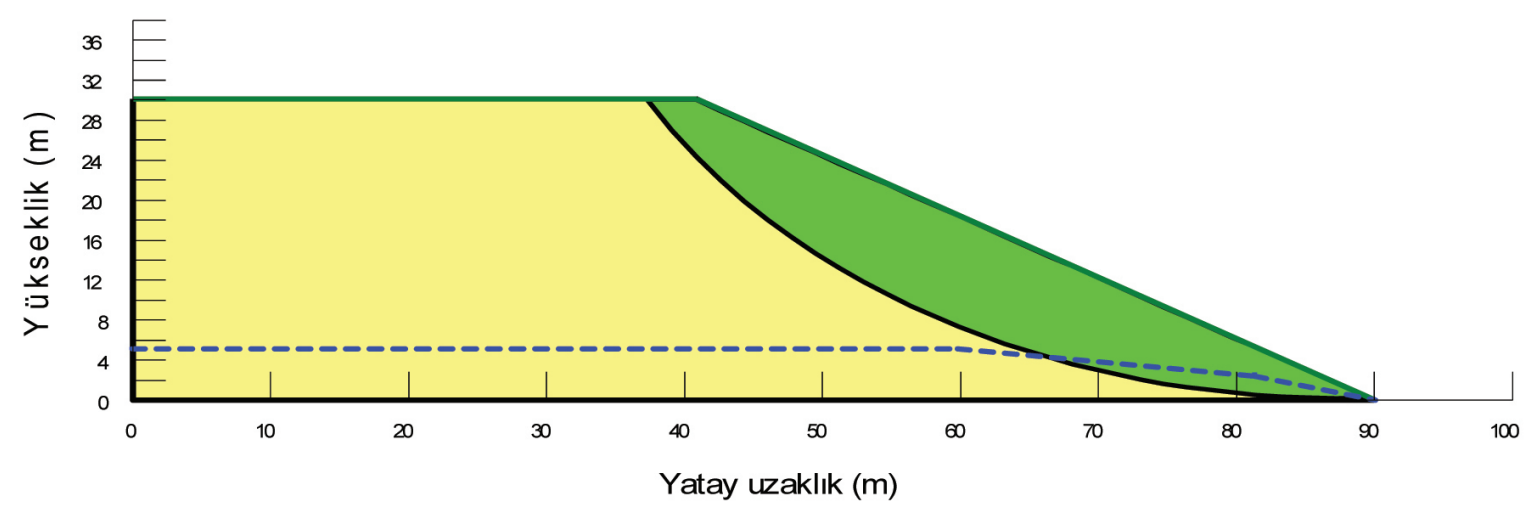

Şekil 13. $30 \mathrm{~m}$ yüksekliğindeki su tablası içeren şev kesiti.

Figure 13. $30 \mathrm{~m}$ height slope section with the groundwater table. 
farklı yükseklik ve genel şev açılarının dikkate alındığ1 analizler gerçekleştirilmiştir. Çalışma alanında pasa yığınları için ortalama $34-35^{\circ}$ 'lik bir döküm açısı söz konusudur. Çok basamaklı şev tasarımlarında çalışma sahasında gözlenen pasa yükseklik değer aralığını içerecek şekilde üç farklı genel şev yüksekliği için $35^{\circ}$ 'lik basamak şev açısı değeri kullanılarak doğaya yeniden kazandırma yönetmeliğindeki ölçütlere uygun olarak basamak genişliği ve yüksekliği düzenlemesi yapılmıştır.

Duraylilık analizlerinde pasalar için değişik araştırmacılar tarafindan (Huang, 1983; Marshall ve Lagather, 1979) önerilmiş olan güvenlik katsayısı değerleri $(F=1.3$ ve $F=1.5)$ kullanılmıştır. Analizlerde SLOPE/W(Geo-Slope International Ltd., 2004) yazılımı kullanılmıştır. Duraylilık analizleri 10, 20 ve 30 metrelik tek basamaklı genel şev yükseklik değerleri için gerçekleştirilmiş olup analizlerde dairesel kaymalar için de kullanılan Morgenstern ve Price (1965) yönteminden elde edilen sonuçlar esas alınmıştır. Ayrıca Hoek ve Bray (1977) tarafindan geliştirilmiş olan dairesel kayma diyagramlarının kullanıldığı basit analiz yöntemi kullanılarak elde edilen duraylılık analiz sonuçları da alternatif olarak sunulmuştur. Şekil 14 ve 15 'te doğaya yeniden kazandırma yönetmeliği üst sınırı kesikli çizgilerle ifade edilmiş ve analiz sonuçlarına göre belirlenmiş olan genel şev açısı ve yüksekliği arasındaki ilişkiler verilmiştir.

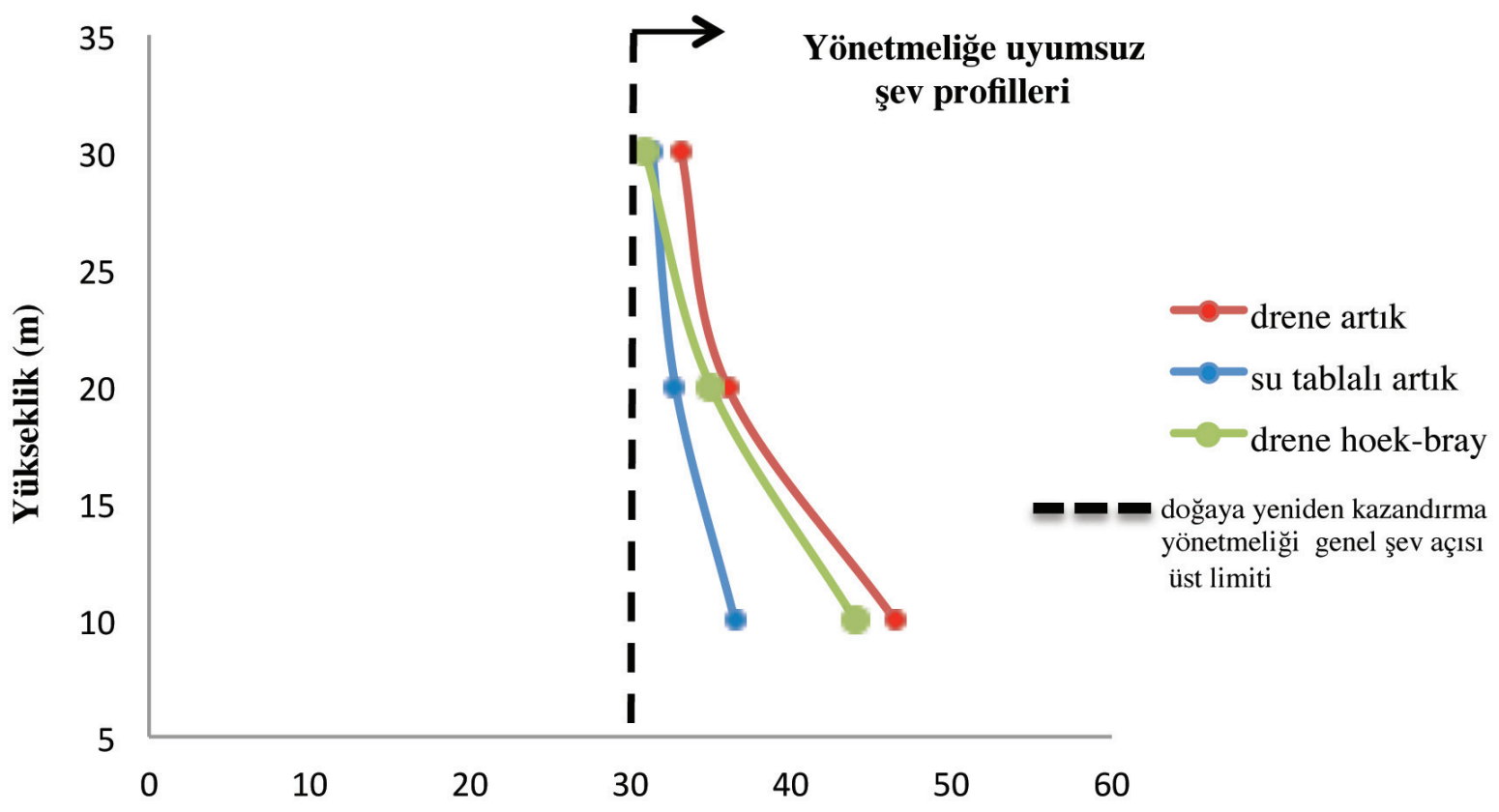

Şev açısı (derece)

Şekil 14. $\quad \mathrm{F}=1.3$ koşulu için genel şev açısı ve pasa yüksekliği arasındaki ilişkiler.

Figure 14. The relationships between the overall slope angle and the spoil height for $F=1.3$ 


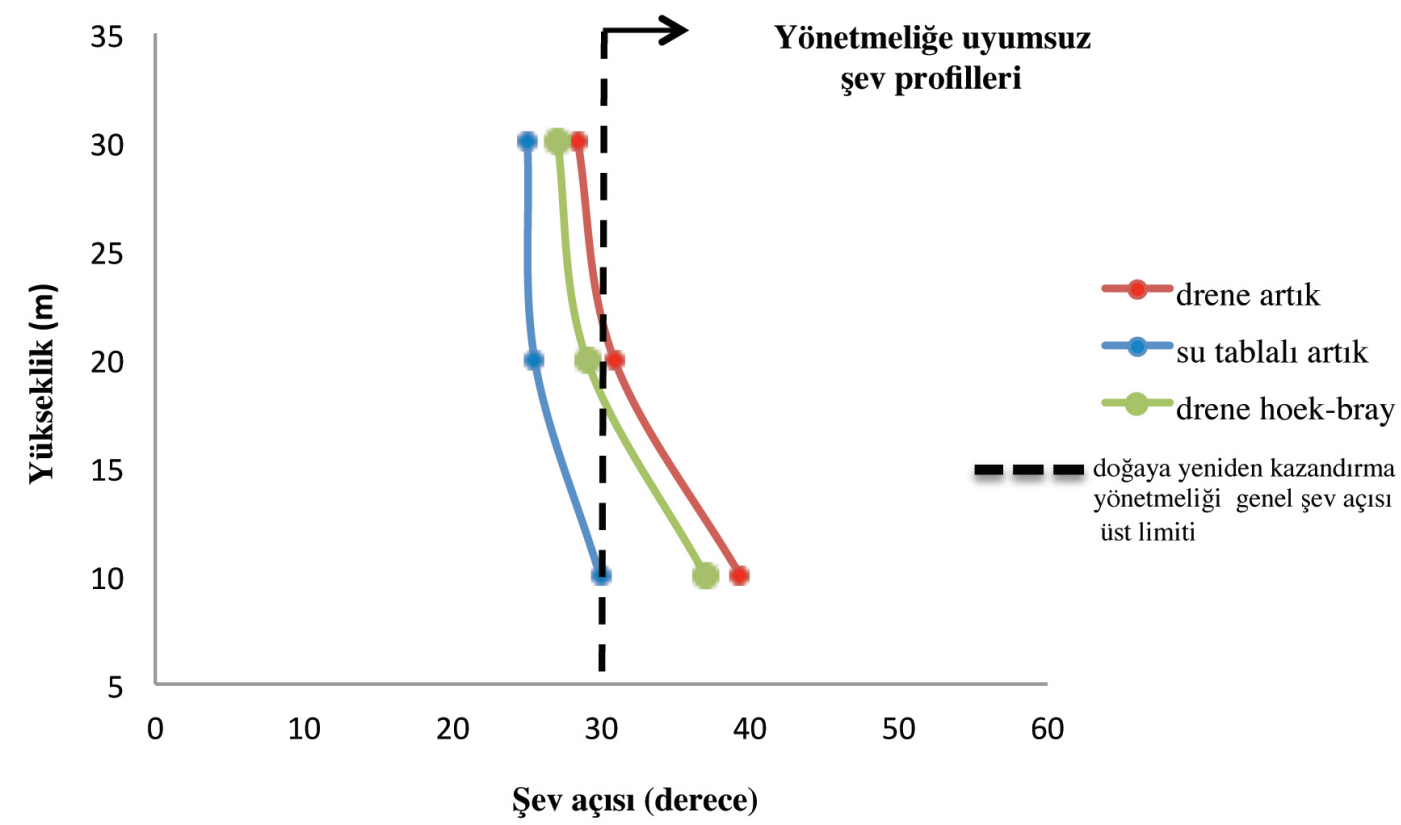

Şekil 15. F $=1.5$ koşulu için genel şev açısı ve pasa yüksekliği arasındaki ilişkiler.

Figure 15. The relationships between the overall slope angle and the spoil height for $F=1.5$.

Kesikli çizgilerle ifade edilen sınır değerinin sağında bulunan şev geometrileri yönetmeliğe uymamaktadır. Bu nedenle bu grafiklerde $30^{\circ}$ üst sınırına kadar eğriler kullanılarak şev geometrileri belirlenirken eğrilerin $30^{\circ}$ den daha büyük şev açılarına karşılık gelen kısımları (kesikli çizginin sağına düşen kısım) doğaya yeniden kazandırma yönetmeliğine uyum göstermemekte ve yönetmelik gereği buralarda $30^{\circ}$ üst sınırının kullanılması gerekmektedir. Şekil 14 ve 15 'ten görülebileceği gibi Morgenstern ve Price (1965) ve Hoek ve Bray (1977) yöntemleri kullanılarak elde edilen sonuçlar birbirlerine çok yakındır.

Çok basamaklı şev geometrilerinin oluşturulmasında, Madencilik Faaliyetleri ile Bozulan Arazilerin Doğaya Yeniden Kazandırılması Yönetmeliği'nde (2010) belirlenmiş olan basamak yüksekliğinin en fazla
$3 \mathrm{~m}$ ve basamak genişliğinin en az $5 \mathrm{~m}$ olacak şekilde düzenlenmesi hususundaki maddesi dikkate alınmıştır. Çalışma alanındaki pasaya ait döküm açısının $35^{\circ}$ olması nedeniyle, çok basamaklı şev düzenlemelerindeki basamak şev açısı olarak bu değer dikkate alınmıştır. 10, 20 ve 30 metrelik şev yükseklikleri için yapılan çok basamaklı şev düzenlemeleriyle ilgili olarak kullanılan değişkenler Çizelge 4'te verilmiş olup, 3 farklı şev yüksekliği için gerçekleştirilen çok basamaklı şev düzenlemeleri için elde edilen genel şev açısı değerleri $19^{\circ}$ civarındadır. Bu değerin, tek basamaklı şev düzenlemeleri için $\mathrm{F}=1.3$ ve $\mathrm{F}=1.5$ durumları için elde edilen genel şev açısı değerlerinden düşük olduğu görülmektedir. 20 metrelik yükseklik için öngörülen çok basamaklı şev düzenlemesi örnek olarak Şekil 16'da verilmiştir. 
Çizelge 4. Çok basamaklı şev düzenlemeleri ile ilgili olarak kullanılan değişkenler ve güvenlik katsayısı değerleri.

Table 4. Variables used for multi-bench slope designs and factor of safety values.

\begin{tabular}{lllllllll}
\hline $\mathrm{H}(\mathrm{m})$ & $\mathrm{n}($ adet $)$ & $\mathrm{h}(\mathrm{m})$ & $\mathrm{x}(\mathrm{m})$ & $\mathrm{d}(\mathrm{m})$ & $\mathrm{BŞA}\left({ }^{\circ}\right)$ & $\mathrm{GŞA}\left({ }^{\circ}\right)$ & $\mathrm{F}$ & $\mathrm{F}_{\text {su tablalı }}$ \\
\hline 10 & 4 & 2.5 & 3.6 & 5 & 35 & 18.8 & 2.97 & 2.16 \\
20 & 7 & 2.86 & 4.08 & 5 & 35 & 18.9 & 2.23 & 1.92 \\
30 & 10 & 3 & 4.3 & 5 & 35 & 18.8 & 1.95 & 1.74 \\
\hline
\end{tabular}

Burada; H: şev yüksekliği, d: basamak genişliği, h: basamak yüksekliği, x: basamağın yatay uzunluğu, BŞA: basamak şev açısı, GŞA: genel şev açısı ve n: basamak sayısıdır.

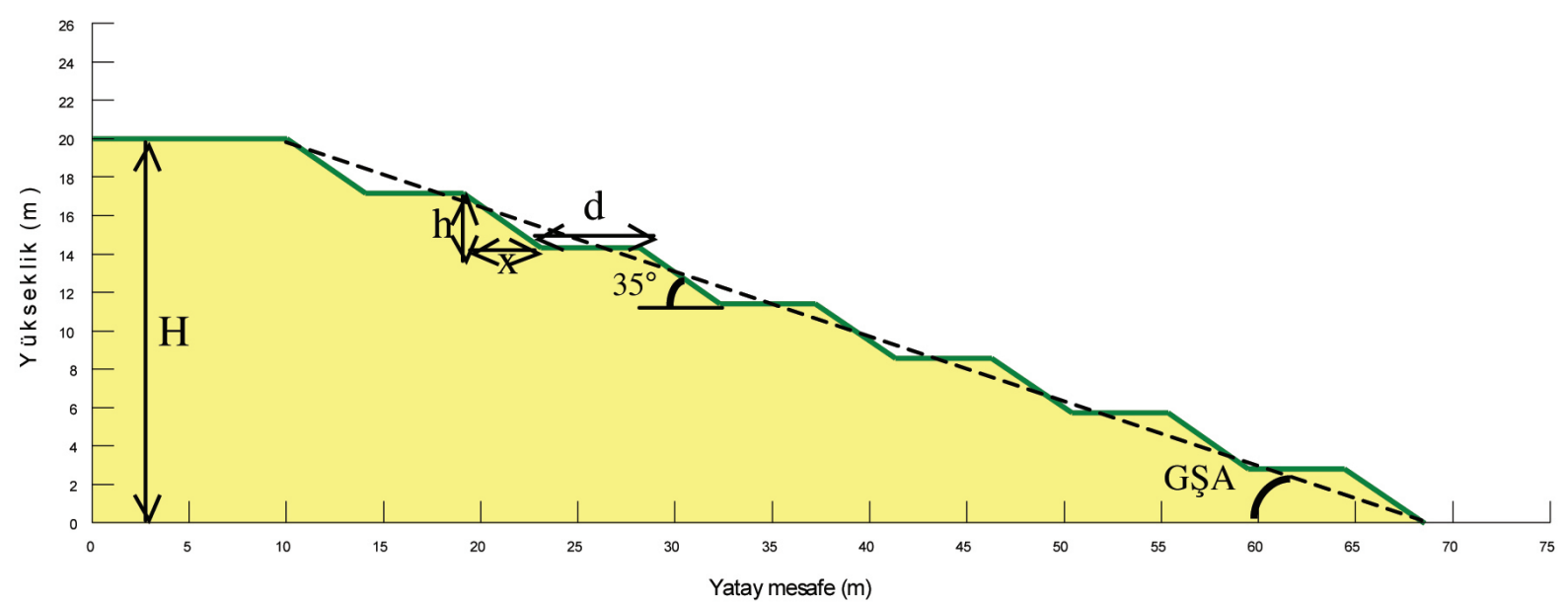

Şekil 16. 20 metrelik şev yüksekliği için çok basamaklı şev düzenlemesi ve kullanılan değişkenler.

Figure 16. Multi-bench slope design and the variables used for the $20 \mathrm{~m}$ slope height.

\section{SONUÇLAR VE ÖNERILER}

$\mathrm{Bu}$ çalışmada Yeniköy Linyitleri İşletmesi'nde (YLİ) yer alan Yaylı tepe pasa döküm sahasındaki pasa yığınları için geçerli olan duraysızlık türü ve pasa yığınlarının jeomekanik özellikleri araştırılmıştır. Laboratuvar deneyleri sonucunda pasa malzemesinin geniş bir tane boyu aralığına sahip, düşük kohezyonlu ve düşük plastisiteli bir malzeme olduğu belirlenmiştir. Saha gözlemleri ve önceki çalışmaların incelenmesi sonucu sert taban üzerine yığılmış pasalar için tabandan bağımsız ve dairesel duraysızlık türünün geçerli olduğu anlaşılmıştır. Geriye dönük analizler sonucunda pasa yığınlarında gelişen duraysızlıklar sırasında kayma yüzeyleri boyunca etkin olan makaslama dayanımı özelliklerinin pasa malzemesinin laboratuvarda tayin edilmiş olan artık dayanım değerleri ile uyumlu olduğu anlaşılmıştır. Pasa yı̆̆ınları için gerçekleştirilmiş olan şev duraylılık analizlerinde $\mathrm{F}=1.3$ ve $\mathrm{F}=1.5$ güvenlik katsayıs 1 
değerleri ve Madencilik Faaliyetleri ile Bozulan Arazilerin Doğaya Yeniden Kazandırılması Yönetmeliği'nde (2010) yer verilmiş olan hususlar dikkate alınmıştır. $\mathrm{F}=1.3$ ve $\mathrm{F}=1.5$ güvenlik katsayıları esas alınarak yapılan tek basamaklı analizlerde, yönetmelikte ifade edilen genel şev açısı üst sınırını aşan değerler elde edilmiştir. Çok basamaklı analizlerde elde edilen genel şev açısı değerleri ise, tek basamaklı analizlerde aynı yükseklik değerlerinde $\mathrm{F}=$ 1.3 ve $F=1.5$ güvenlik katsayıları için elde edilenlere göre daha düşüktür. Diğer bir ifadeyle, çok basamaklı şev tasarımları için Madencilik Faaliyetleri ile Bozulan Arazilerin Doğaya Yeniden Kazandırılması Yönetmeliği'nde (2010) belirtilen kuralların esas alınması durumunda elde edilen güvenlik katsayıları tek basamaklı pasa şevi analizlerinde esas alınan $F=1.3$ ve $\mathrm{F}=1.5$ güvenlik katsayısı değerlerinden daha yüksek olarak belirlenmiştir. Bu durum, söz konusu yönetmeliğin pasa malzemesi için $\mathrm{F}=$ 1.5 olarak belirlenmiş tasarımlara oranla daha güvenli tarafta kaldığını göstermektedir.

Daha güvenli şev tasarımının yanı sıra çeşitli sayısal sınırlamaların (tek basamaklı şevler için yüksek şev açısı sınır değerinin $30^{\circ}$ ve çok basamaklı şevler için basamak yüksekliğinin en fazla 3 metre olması gibi) ifade edildiği Madencilik Faaliyetleri ile Bozulan Arazilerin Doğaya Yeniden Kazandırılması Yönetmeliği (2010) şev duraylılığı ile ilgili olarak farklı çalışma aşamalarında (örnekleme, laboratuvar deneyleri, duraylılık analizleri) yapılabilecek olası hatalı sonuç ve değerlendirmelerin önüne geçilmesi açısından faydalı olacağ1 düşünülmektedir. Ancak özellikle yüksek şev açıları ile güvenli bir şekilde oluşturulabilecek sağlam zeminlerde söz konusu yönetmeliğin daha fazla hafriyat miktarına (dolayısıyla daha yüksek maliyete) karşılık gelen tasarım seçeneklerini üreteceği de gözden kaçırılmamalıdır.

\section{KATKI BELİRTME}

Bu çalışmada, MTA Genel Müdürlüğü'nün "Maden Sahalarının Doğaya Yeniden Kazandırılması: Yeniköy Linyitleri İşletmesi (YLI) Yaylıktepe Sahası Örneği” adlı projenin (Demirbugan vd., 2013) fiziksel duraylil1k ve iyileştirme bölümüne ait veriler kullanılmıştır. Yazar makalenin geliştirilmesinde değerli katkı ve önerilerinden dolayı Prof. Dr. Reşat Ulusay’a teşekkür eder.

\section{KAYNAKLAR}

Apaydın, N., Ulusay, R., 1990. TKİ-GELİ Milas Sekköy Açık İşletmesi Jeoteknik Etüdü Sonuç Raporu. MTA Derleme No. 8955, 114 s (yayımlanmamış).

ASTM, 1994a. Annual Book of ASTM StandardsSoil and Rock, Building Stones. Section-4, Construction, V. 04.08. ASTM Publication, 972 p.

ASTM, 1994b. Standard classification of soils for engineering purposes (Unified Soil Classification System). ASTM D2487, 206-215.

Bradfield, L., Simmons, J., Fityus, S., 2013. Issues related to stability design of very high spoil dumps. $13^{\text {th }}$ Coal Operators' Conference, University of Wollongong, The Australasian Institute of Mining and Metallurgy \& Mine Managers Association of Australia, 376-386.

Demirbugan, A., Karakul, H., Avc1, K., 2013. Maden Sahalarının Doğaya Yeniden Kazandırılması 
Yeniköy Linyitleri İşletmesi (YLI) Yaylıktepe Sahası Örneği. MTA Derleme No. 11618, 131 s (yayımlanmamış).

Geo-Slope International Ltd., 2004. Slope/W software. Vers. 6.2, Calgary, Canada.

Hoek, E., Bray, J.W., 1977. Rock slope engineering. Institute of Mining and Metallurgy, London, 402 p.

Huang, Y.H., 1983. Stability Analysis of Earth Slopes. Van Nostrand Reinhold Company, New York, $305 \mathrm{p}$.

Jeldes, I.A., Drumm, E.C., Schwartz, J.S., 2013. The low compaction grading technique on steep reclaimed slopes: Soil characterization and static slope stability. Geotechnical and Geological Engineering, 31, 1261-1274.

Kaşmer, Ö., Ulusay, R., 2006. Stability of spoil piles at two coal mines in Turkey: geotechnical characterization and design considerations. Environmental and Engineering Geoscience, 12 (4), 337-352.

Kaşmer, Ö., Ulusay, R., Gökçeoğlu, C., 2006. Spoil pile instabilities with reference to a strip coal mine in Turkey: mechanisms and assessment of deformations. Environmental Geology, 49, 570585 .

Madencilik Faaliyetleri İle Bozulan Arazilerin Doğaya Yeniden Kazandırılması Yönetmeliği. 2010. T.C. Resmi Gazete, 27471, 23 Ocak 2010.

Marshall, R., Lagather, R.B., 1979. Design guidelines for coal refuse piles and water, sediment or slurry impoundments and impounding structures. US Department of of Labor, IR1109, 29 p.

Morgenstern, N.R., Price, V.E., 1965. The analysis of the stability of general slip surface. Geotechnique, 15, 79-93.

Stormont J.C., Farfan E., 2005. Stability evaluation of a mine waste pile. Environmental and Engineering Geoscience, 11 (1), 43-52.

Ulusay, R., Yoleri, M.F., Çağlan, D., Arıkan, F., 1994. TKİ-GELİ Eskihisar (Yatağan-Muğla) Linyit Açık İşletmesi Pasa Yığınlarının Şev Stabilitesi ve Tasarımı. MTA Derleme No. 9685, 194 s (yayımlanmamış).

Ulusay, R., Arıkan, F., Yoleri, M.F., Çağlan, D., 1995a. Engineering geological characterization of coal mine waste material and an evaluation in the context of back-analysis of spoil pile instabilities in a strip mine, SW Turkey. Engineering Geology, 40, 77-101.

Ulusay, R., Yoleri, M.F., Çağlan, D., Arıkan, F., 1995b. Design evaluations for spoil piles at a strip coal mine considering safety of the haul road. International Journal of Surface Mining, Reclamation and Environment, 9, 133-140.

Yiğitel, İ., 1978. Muğla-Milas kömürlü Neojeni Sekköy sektörü. jeoloji raporu, MTA Enerji Hammaddeleri Dairesi Raporu, 15 s. (yayımlanmamış).

Yücel, Z, Özoran, B., Çekinmez, V., 1990. TKİ-GELI Milas-Sekköy Bölgesi Ekizköy Açık Ocağı Jeoteknik Etüdü Sonuç Raporu. MTA Derleme No. 8954, 56 s (yayımlanmamış). 